\title{
Implementation of User Anthropometry Bale "Sakenem" Buildings based on Height Bataran and Height Bale-bale in Singapadu Tengah Village, Gianyar \\ I Wayan Parwata ${ }^{1}$, Anak Agung Gede Oka Wisnumurti ${ }^{2}$, Ni Wayan Meidayanti Mustika ${ }^{3}$
}

\begin{abstract}
Bale Sakenem Building is one of the buildings that were in the order of Traditional Bali House. This study identified Bale Sakenem building located in the Central Singapadu Village and that is observational research by using cross sectional design. This research was done by means of retrospective observational that is considered the factor that can affect Bale Sakenem Building Anthropometry. From the data analyze of research identification, $30 \%$ height bataran not in accordance with the average size of an ideal height bataran and $20 \%$ height bale-bale also not in accordance with the average of the ideal height bale-bale in Bale Sakenem building in the Central Singapadu Gianyar have not yet undertaken anthropometry users and more dominant to follow measurements that based on the size of Undagi, as a consequence there was uncomfortableness. Height bataran and height bale-bale is based on the tolerance of anthropometry using the 95 percentile and 5 percentile for tolerance limit
\end{abstract}

Keywords-Anthropometry, Balinese Architecture, Culture, Percentile, User Comfort.

\section{INTRODUCTION}

$\mathrm{R}$ esearch on the architecture, the people and the environment is an interesting relationship to continue to study. Similarly, Balinese architecture is strongly associated with the user and the surrounding environment. Parwata research results (2011) states that the development of innovation in traditional Balinese residences remain guided by the anthropometry of the Balinese as users of the building, so that the suitability and user convenience can be felt ${ }^{[1]}$.

Traditional Balinese architecture built following the layout, spatial and building on the concept of Asta Kosala Kosali ${ }^{[2]}$. This concept is one of the concepts used in the arrangement of the house or building techniques that are based on the sacred human anatomy (anthropometry) owner. This concept is still used in traditional construction of residential houses in Bali in accordance with the foundation of philosophical, ethical, and ritual with regard conception embodiment, selecting the land, good day (dewasa ayu) to build houses, as well as the ceremony (yadnya) in its development ${ }^{[3]}$.

Size of building land in several hamlets in the Singapadu Tengah village. Ayahan land village is a piece of land given by the village local custom where people live which measure the extent determined by the levels of color (caste), position and dadia (groups / communities of citizens in the number of

${ }^{1}$ Faculty of Engineering, Warmadewa University, 80235 Denpasar Bali, Indonesia (corresponding author to provide phone: 081337777897; e-mail iwayanparwata01@gmail.com).

${ }^{2}$ Faculty of Social and Politics, Warmadewa University, 80235 Denpasar Bali, Indonesia (e-mail: wisnumurtibali@yahoo.com).

${ }^{3}$ Faculty of Engineering, Warmadewa University, 80235 Denpasar Bali, Indonesia (e-mail: meida_mustika@yahoo.com). families) and can be used for generations by the rules villages applicable ${ }^{[4]}$.

Generally building "sakenem" Shudra caste is owned by citizens, in accordance with the size of the land given by the indigenous villages ${ }^{[5]}$. Each occupant in the land has a responsibility towards their traditional villages such as: participate and build and maintain public buildings owned by the village, set up a ceremony associated with custom activities and some activities that must be obeyed citizens. Residents who owns the building "sakenem" is certainly the size of the land is narrower than the citizens who own the building "sakutus" or "sakaroras". And if forced to construct buildings "sakutus" or "sakaroras" in her yard, and the layout of the building is crowded, uncomfortable and even a shift in values, layout and spatial in Balinese architecture. ${ }^{[8]}$

This study focuses on the building of Bali "sakenem" particularly at the height bataran and height bale-bale. The expected outcome of this research is to create a prototype height bataran and height bale-bale on the building "sakenem" in the village of Singapadu Tengah. This research is also expected to generate Intellectual Property Rights (IPR) in the building "sakenem".

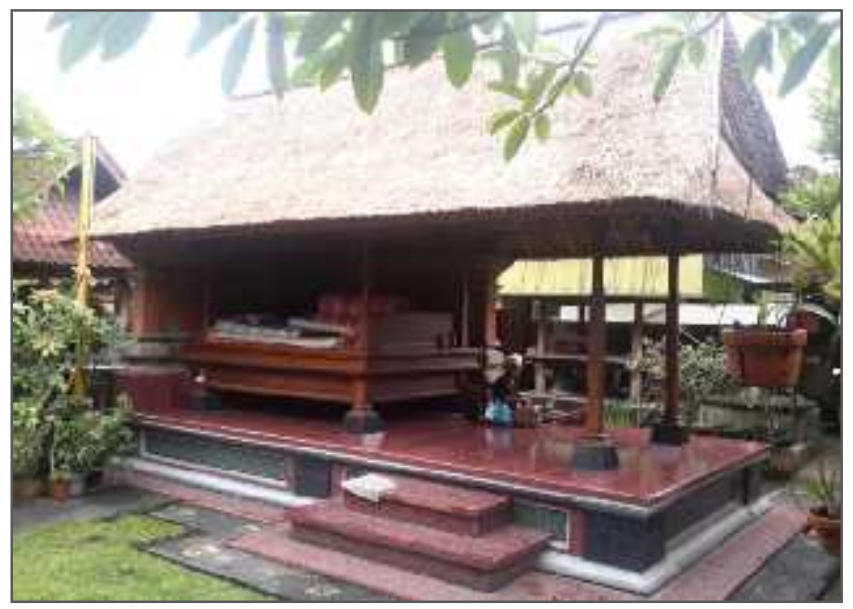

Fig. 1 Bale "Sakenem” Building

The results of this study are also expected to contribute to building measure "sakenem" by using the size of the "meter", in several variables can also be used for building more functionality, both traditional building and modern Balinese in accordance with the development based on the anthropometry of the owner of the building who were in Bali or outside Bali ${ }^{[9]}$. 


\section{RESEARCH METHOD}

This study was an observational study using cross sectional design. The study conducted by means of an observational retrospective of assessing factors that may affect anthropometry Bale Building "Sakenem". This crosssectional study can be used to see the distribution of measurement results of the independent variables ${ }^{[7]}$. The dependent variable in this study is anthropometry of Bale "sakenem" Building, while the independent variables are height bataran and height bale-bale. The measuring tools or instrument used in this study are as follows:

a. questionnaire comfort about height bataran and height bale-bale that have been tested during the preliminary research and analyzed the validity and reliability;

b. camera with 15 mega pixel level of accuracy, the brand "Nikon" made in Japan, which is used to the document of research activities;

c. antropometer "Super 686" made in Japan with the level of precision of $1 \mathrm{~mm}$ to measure anthropometric occupants;

d. Measuring Tape brand "MDS" $7.5 \mathrm{~m}$ (25 ft) made in Indonesia.

\section{EQUATIONS}

In this study, the formula used anthropometric tolerance limit (percentile) is as follows.

$$
P=x+\sigma x(Z)
$$

Percentile calculation tolerance limit of $95 \%$ and $5 \%$ percentile in height bataran can be seen as follows:

- 95 percentile (maximum percentile)

$\mathrm{P} 95=\mathrm{x}+\sigma \mathrm{x}(\mathrm{Z} 1)$

$\mathrm{P} 95=80+9.47(1.645)$

$\mathrm{P} 95=80+15.58$

$\mathrm{P} 95=95.58 \mathrm{~cm}$

$\mathrm{P} 5=\mathrm{x}+\sigma \mathrm{x}(\mathrm{Z} 2)$

5 percentile (minimum percentile)

$\mathrm{P} 5=80+9.47(-1.645)$

$\mathrm{P} 5=80-15.58$

$\mathrm{P} 5=64.42 \mathrm{~cm}$

\section{Nomenclature :}

$\mathrm{P} 95=95 \%$ percentile

$\mathrm{P} 5=5 \%$ percentile

$\mathrm{x}=$ average height bataran

$\sigma \mathrm{x}=$ standard deviation

$\mathrm{Z} 1=+1.645$

$\mathrm{Z} 2=-1.645$

Calculation of height tolerance limits bale-bale using a percentile $95 \%$ and $5 \%$ percentile in height calculation balebale can be seen as follows:

- 95 percentile (maximum percentile)

$\mathrm{P} 95=\mathrm{x}+\sigma \mathrm{x}(\mathrm{Z} 1)$

$\mathrm{P} 95=78+4.59(1.645)$

$\mathrm{P} 95=78+7.55$

$\mathrm{P} 95=85.55 \mathrm{~cm}$

- 5 percentile (minimum percentile)
$\mathrm{P} 5=\mathrm{x}+\sigma \mathrm{x}(\mathrm{Z} 2)$

$\mathrm{P} 5=78+4.59(-1.645)$

$\mathrm{P} 5=78-7.55$

$\mathrm{P} 5=70.45 \mathrm{~cm}$

\section{Nomenclature :}

P95 $=95 \%$ percentile

$\mathrm{P} 5=5 \%$ percentile

$\mathrm{x}=$ average height bale-bale

$\sigma \mathrm{x}=$ standard deviation

$\mathrm{Z} 1=+1.645$

$\mathrm{Z} 2=-1.645$

\section{FIGURES AND TABLES}

\section{A. The Measurement of Height Bataran}

Height bataran is an important variable in this study was measured by comparing the measured height with height bataran ideal (standard) based on interviews with masons (undagi).

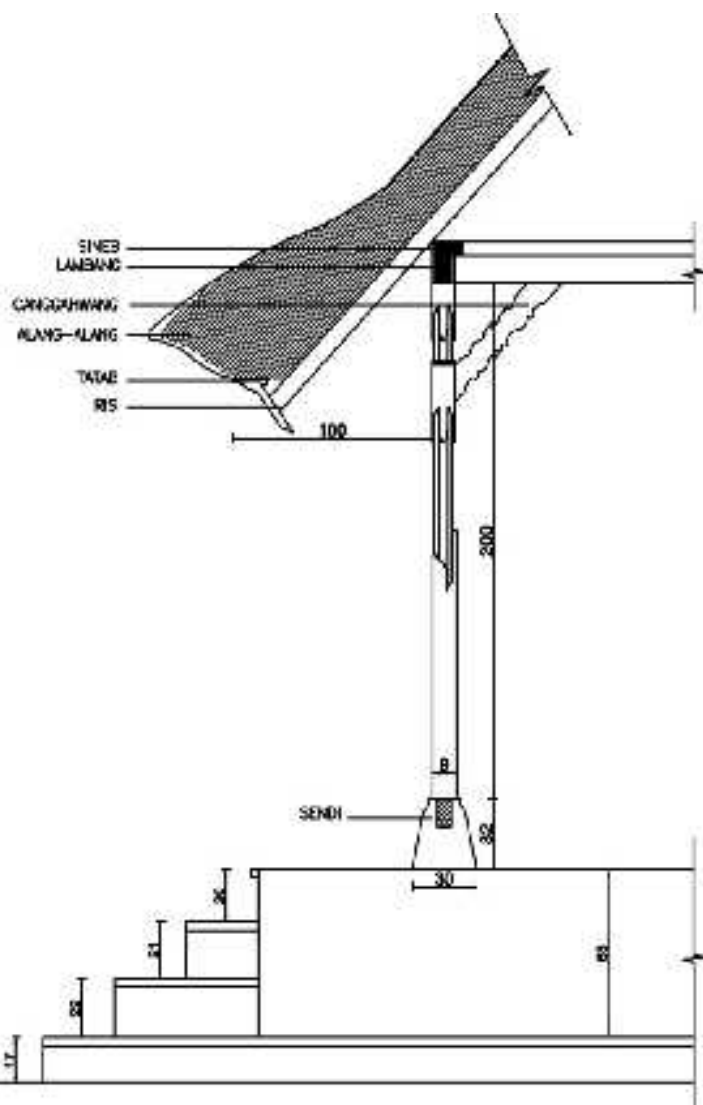

Fig. 2 Height Bataran

Ideal height bataran according to experts (undagi) in the Singapadu Tengah village, said that ideally a height bataran is $80 \mathrm{~cm}$. The ideal height bataran can create user comfort main space of the user when the move in bale "sakenem" building and in terms of appearance creates a bale building form "sakenem" more proportional. Height bataran measurement is done by measuring the distance between the ground floor of the bale "sakenem" building. 


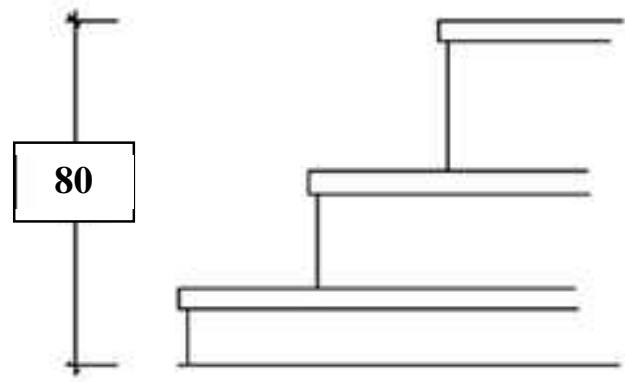

Fig. 3 Average Height Bataran

\section{The Comparison of Height}

\section{Bataran and Tolerance Limit}

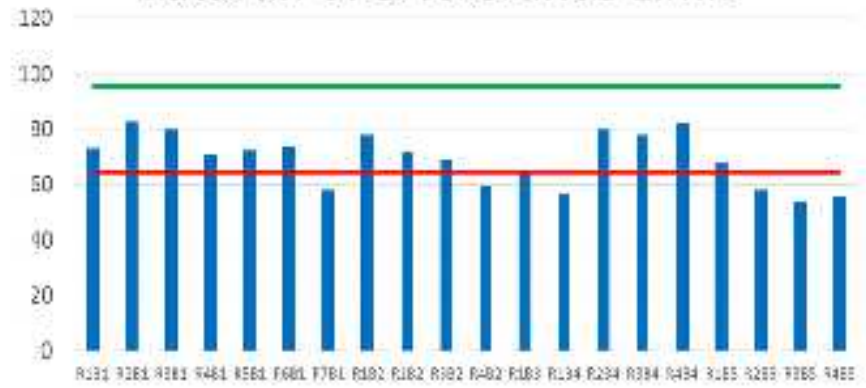

Tinggi Bataran -MIN - MAX

Fig. 4 The Comparison of Height Bataran and Tolerance Limit

Based on the calculation can be seen that the tolerance limits of height bataran minimum value is $64.42 \mathrm{~cm}$. Maximum value for the tolerance limit (percentile 95\%) obtained result is $95.58 \mathrm{~cm}$. In this study means that height bataran less than 64.42 centimeters and 95.58 centimeters exceeded yet meet the standards of user comfort. Based on the results figure of height bataran measurements known that $30 \%$ of height bataran that have been measured do not appropriate with the standards of the user's convenience. It is known from many height bataran less than $64.42 \mathrm{~cm}$. Height bataran is too low and does not match with these standards led to at least the movement of the user and bale "sakenem" building that looks less proportionately. Moreover, when it rains the rain water can easily get into the bale "sakenem" building because the floor is too low and the shape of the building were open making it easier for water to pour into the building. Height bataran not yet meet the standards of comfort is still influenced by the builder (undagi) which makes building bale "sakenem" where undagi size of each guideline in making Bale "Sakenem" Building.

\section{B. The Measurement of Height Bale-bale}

Bale-bale in bale "sakenem" building is the place or bedding that is open and functioned as a Hindu religious ceremony in Bali. Bale-bale is one of the important components in bale "sakenem" building. Bale-bale in a bale "sakenem" building flanked by four columns (saka) as a buffer. Height bale-bale measurement is done by measuring the distance between the building floor bale "sakenem" with pedestal bench.

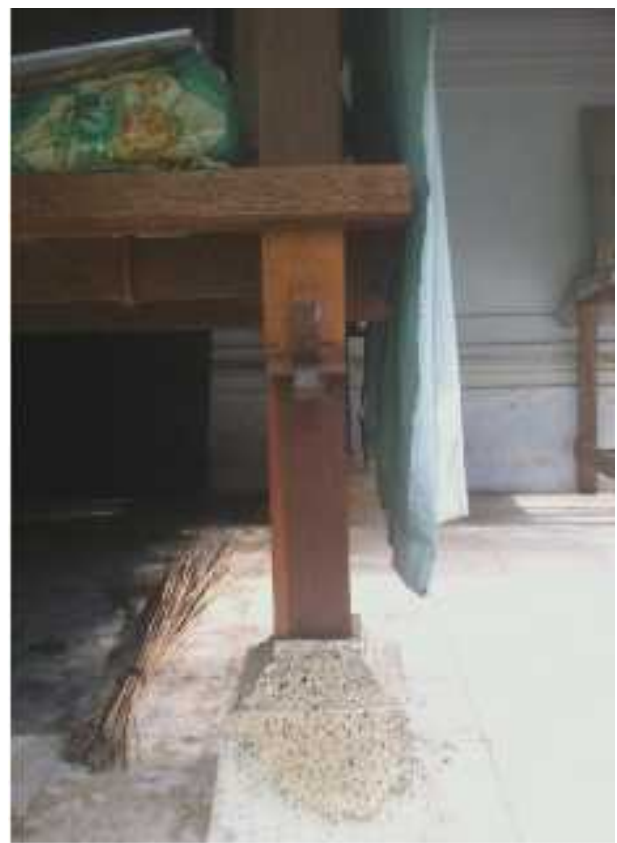

Fig. 5 Height Bale-bale

Height bale-bale is a variable in this study was measured by comparing the height bale-bale measured with ideal height bale-bale (standard) where the standard rate of height bale-bale obtained through interviews with masons (undagi). According to experts (undagi) in the Singapadu Tengah village, ideal height bale-bale in a bale "sakenem" building which has a height of $78 \mathrm{~cm}$.

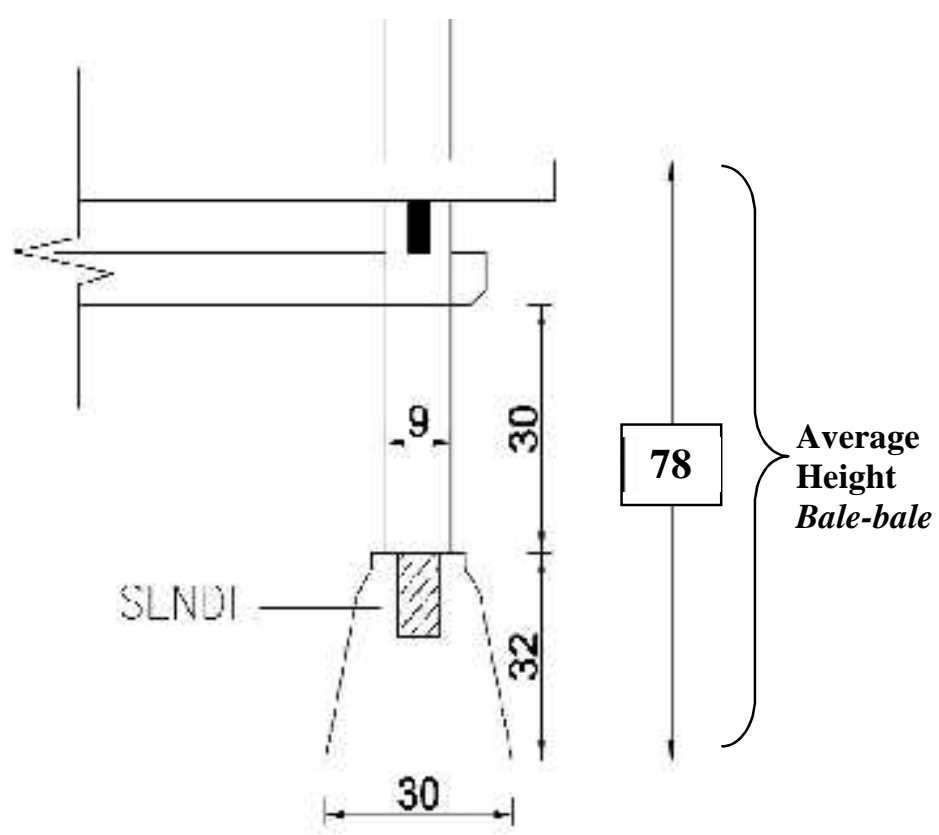

Fig. 6 Average Height Bale-bale 


\section{The Comparison of Height Bale-bale and Tolerance Limit}

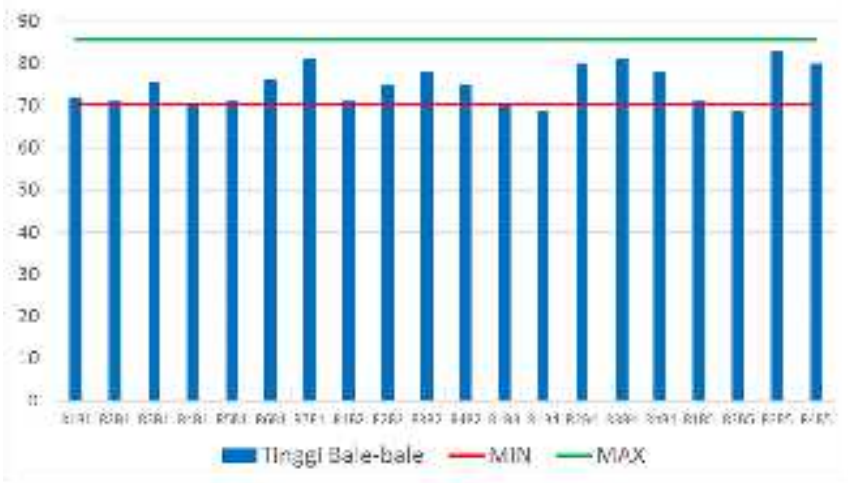

Fig. 7 The Comparison of Height Bale-bale and Tolerance Limit

Based on the calculation of tolerance limits above can be seen that the tolerance limit of the minimum value (5\% percentile) of the bale-bale height is $70.45 \mathrm{~cm}$. Maximum value for the tolerance limit (percentile 95\%) obtained result is $85.55 \mathrm{~cm}$. In this research could mean that the height bench less than $70.45 \mathrm{~cm}$ and $85.55 \mathrm{~cm}$ beyond the tolerance limit and do not meet the standards do not meet the user's convenience. Based on the comparison between the results figure height measurement bench with a tolerance limit of $20 \%$ is known that height-bale-bale that has been measured yet meet the standards of comfort of the user. Height balebale that is too low causes the bale-bale did not meet the standards of comfort thus inhibiting the movement of the user in performing religious ceremonies that take advantage of the functions of the bale-bale, and to influence the shape of the bale "sakenem" building disproportionate. While the height bale-bale that exceeds the tolerance limit cause the least space of the user so that the building bale "sakenem" looks less proportionately. In addition, the convenience of users need to be considered when being active in the bale-bale so that the bale-bale height ideal is very important to avoid the inconvenience, especially when on the do activity. Height bale-bale become a very important component in bale "sakenem" building because utilization bench components are most often used for religious ceremonies. In manufacturing, building bale "sakenem" are usually made by the undagi where the size of each guideline and does not suit the user's needs so that the height mismatch of bale-bale ideal size still found. This greatly affects the comfort of the user in the move in bale "sakenem" building.

\section{CONCLUSION}

$1.30 \%$ of height bataran that have been measured do not appropriate with the standards of the user's convenience.

$2.20 \%$ of height bale-bale that have been measured do not appropriate with the standards of the user's convenience.

3. Bale "Sakenem" building seen from height bataran and height bale-bale aspect in the Singapadu Tengah village Gianyar have not yet undertaken anthropometry users and more dominant to follow measurements that based on the size of Undagi, as a consequence there was uncomfortableness.

\section{REFERENCES}

[1] Parwata I Wayan (2011), Rumah Tinggal Tradisional Bali dari Aspek Budaya dan Antropometri, Jurnal Mudra: Volume 26 Nomor 1, Januari 2011, p95-106

[2] Bija, I Made, (2012)., Asta Kosala-Kosali Asta Bumi, Pustaka Bali Post: Depasar

[3] Witana, I Nyoman (1973), Asta Kosala Kosali: Ketentuan Adat Tradisional mengenai Bangunan Bali, Building Information Centre, Dinas Pekerjaan Umum Prop. Bali

[4] Parwata I Wayan (2009), Ergonomic Intervention by Ventilation and Windows Remodeling Increases Comfort of Occupants of Houses Type 36/120 in Nuansa Kori Housing Sading Mengwi Badung, Majalah Ilmu Faal Indonesia, Vol. 9 / No. 1 / Published : 2009-10

[5] Mulyati, Made Ida (2012), Prinsip Ergonomis Dalam Produk dan Sikap Kerja, www.google.co.id/\#q=TATA+ATURAN+PEMBANGUNAN+RUMA H+TRADISIONAL+BALI\&hl=id\&prmd=imvns\&ei=2YErT_GZOpGr rAefodHUDA\&start $=20 \& s a=N \& b a v=0 n$

[6] Notoatmodjo, S (2005), Pendidikan dan Perilaku Kesehatan, Jakarta: Rineka Cipta.

[7] Nursalam, (2008), Konsep dan Penerapan Metodologi Penelitian Ilmu Keperawatan, Editor: Tim Editor Salemba Medika, Jakarta: Salemba Medika.

[8] Widana, Ida Bagus Gede (2011), Dharmaning Hasta Kosali Arsitektur Tradisional Bali, Penerbit: Dharma Pura: Denpasar.

[9] Wignjosoebroto, Sritomo (2008)., Ergonomi, Studi Gerak dan Waktu: Teknik Analisis untuk Peningkatan Produktivitas Kerja, Edisi Keempat, Cetakan Keempat, Guna Widya: Surabaya. 